\title{
CONFLICTING PERSPECTIVES ON SPOTTED OWLS, WILDFIRE, AND FOREST RESTORATION
}

\author{
Joseph L. Ganey ${ }^{*}$, Ho Yi Wan ${ }^{2}$, Samuel A. Cushman' ${ }^{1}$, and Christina D. Vojta ${ }^{3}$ \\ ${ }^{1}$ USDA Forest Service Rocky Mountain Research Station, \\ 2500 South Pine Knoll Drive, Flagstaff, Arizona 86001, USA \\ ${ }^{2}$ School of Earth Sciences and Environmental Sustainability, Northern Arizona University, \\ P.O. Box 5694, Flagstaff, Arizona 86011, USA \\ ${ }^{3}$ Landscape Conservation Initiative, Northern Arizona University, \\ P.O. Box 5767, Flagstaff, Arizona 86011, USA \\ *Corresponding author: Tel.: +1-928-556-2156; e-mail: jganey@fs.fed.us
}

\begin{abstract}
Evidence of increasing fire extent and severity in the western US in recent decades has raised concern over the effects of fire on threatened species such as the spotted owl (Strix occidentalis Xantus de Vesey), which nests in forests with large trees and high canopy cover that are vulnerable to high-severity wildfire. A dichotomy of views exists on the impact of high-severity wildfire on the spotted owl. One view holds that reduction in the extent of forests with large trees and high canopy cover due to high-severity wildfire is a primary threat to spotted owls, and that fuels reduction treatments that successfully reduce the risk of high-severity wildfire can aid in sustaining desired conditions for this owl. A conflicting view maintains that high-severity wildfire was relatively common in many forest types occupied by spotted owls and does not pose an immediate threat to spotted owls, and that fuels reduction treatments are misguided because they degrade owl habitat and do not
\end{abstract}

RESUMEN

Las evidencias de incrementos en la extensión y severidad de los incendios en el oeste de los EEUU en décadas recientes, ha llamado la atención sobre los efectos del fuego sobre especies amenazadas como el búho moteado (Strix occidentalis Xantus de Vesey), que nidifica en bosques con árboles grandes y con alta cobertura de dosel, y que son vulnerables a fuegos de alta severidad. Existe una dicotomía de miradas sobre el impacto de fuegos de alta severidad sobre el búho moteado. Una de esas miradas sostiene que la reducción en la extensión de bosques con árboles grandes y alta cobertura de sus doseles debido a incendios de alta severidad es una amenaza de primer orden para los búhos moteados, y que los tratamientos de reducción de combustible que reducen exitosamente el riesgo de incendios de alta severidad pueden ayudar en sostener las condiciones deseables para este búho. Una mirada diferente a la anterior sostiene que los incendios de alta severidad fueron relativamente comunes en muchos tipos forestales ocupados por búhos moteados, y que no implican una amenaza inmediata para estos búhos, y que los tratamientos de reducción de combustible son desacertados, ya que degradan el hábitat del 
reduce the extent of high-severity fire. Based on the existing literature, we argue that considerable uncertainty remains regarding the response of spotted owls to high-severity wildfire, especially over longer time frames and across the three subspecies (California [Strix occidentalis occidentalis Xantus de Vesey], Mexican [S. o. lucida Nelson], and northern [S. o. caurina Merriam]) of spotted owls. The considerable extent of high-severity wildfire within the ranges of these subspecies over recent years, coupled with the trend toward increasing extent and severity of megafires, suggests that the cumulative effects of these fires could be significant throughout the range of this owl. Forest restoration or fuels reduction treatments may aid in reducing habitat loss, particularly when strategically located to optimize reduction of fire risk, but also may locally impact spotted owl habitat. We advocate further evaluation of both the impacts of such treatments to spotted owls and the effectiveness of such treatments in mitigating fire behavior. We also advocate wider use of managed fire to reduce risk of high-severity wildfire. Finally, given the paucity of long-term data on this topic, we recommend targeted research aimed at a decade or longer time periods after fires. These studies should include measures of demographic performance, and should be designed to elucidate differences in those metrics related to landscape pattern, forest type, and subspecies ecology. Such information would inform the debate over how to integrate the conservation of spotted owls and their habitat with fuels reduction and forest restoration objectives. búho moteado y no reducen la extensión de los fuegos de alta severidad. Basados en la literatura existente, argumentamos que una considerable incertidumbre persiste relacionada con la respuesta del búho moteado a incendios de alta severidad, especialmente en relación a períodos de tiempo largos y dentro de las tres subespecies (Californica [Strix occidentalis occidentalis Xantus de Vesey], Mexicana [S. o. lucida Nelson], y norteña $[S$. o. caurina Merriam]) de este búho. El considerable aumento de incendios de alta severidad dentro del hábitat de estas subespecies en años recientes, junto con la tendencia sobre un incremento en extensión y severidad de megaincendios, sugiere que los efectos acumulativos de esos incendios pueden ser significativos para el hábitat de este búho. La restauración forestal o los tratamientos de reducción del combustible pueden ayudar a reducir la pérdida de hábitat, particularmente cuando están estratégicamente ubicados para optimizar la reducción de riesgo de incendio, pero también pueden impactar localmente el hábitat del búho moteado. Recomendamos una evaluación más profunda de los impactos de tanto estos tratamientos sobre el búho moteado, como de la efectividad de estos tratamientos en la mitigación del comportamiento del fuego. También recomendamos un uso más amplio de quemas prescriptas para reducir el riesgo de incendios de alta severidad. Finalmente dada la escasez de datos de largo plazo en este tópico, recomendamos estudios orientados a períodos decenales o más largos, después de la ocurrencia del fuego. Estos estudios deben incluir medidas de desempeño demográfico, y deben estar diseñados para dilucidar las diferencias entre aquellas medidas relacionadas con el patrón del paisaje, el tipo forestal, y la ecología de las subespecies. Esta información podría aportar al debate sobre cómo integrar la conservación del búho moteado y su hábitat con la reducción de los combustibles y los objetivos de restauración de bosques. 
Keywords: foraging habitat, fuels reduction, managed fire, megafires, nesting habitat, restoration, spotted owl, Strix occidentalis

Citation: Ganey, J.L., H.Y. Wan, S.A. Cushman, and C.D. Vojta. 2017. Conflicting perspectives on spotted owls, wildfire, and forest restoration. Fire Ecology 13(3): 146-165. doi: 10.4996/ fireecology. 130318020

\section{INTRODUCTION}

Fire historically served as a major disturbance agent structuring forests in the western United States (Agee 1993, Covington et al. 1994, Allen et al. 2002, Baker 2015a). Fire suppression, along with other anthropogenic activities, has altered species composition, forest structure, and fuel complexes in many forest types, leaving these forests vulnerable to high-severity wildfires (Covington and Moore 1994, Allen et al. 2002, Brown et al. 2004). Studies suggest that both size and severity of wildfires has increased in the western US over the past several decades in response to structural changes and changing climate (Littell et al. 2009, Miller et al. 2009, Miller and Safford 2012; but see Odion and Hanson 2006; Williams and Baker 2012; Baker 2015a, b; Hanson and Odion 2016), and climatic projections suggest that these trends will continue as future climate becomes warmer and drier (McKenzie et al. 2004, Westerling et al. 2006, Littell et al. 2009, Allen et al. 2010).

This increase in extent and severity of wildfires resulted in a current management emphasis on restoring Western forests to conditions within their historical range of variability (Keane et al. 2009) in hopes of increasing their resiliency to wildfire (Allen et al. 2002, Brown et al. 2004, Stanturf et al. 2014, Hagmann et al. 2017), culminating in large-scale forest restoration projects (Sisk et al. 2005, North et al. 2009, Roccaforte et al. 2010). These efforts are controversial and the subject of debate, however. A species of particular interest in this debate is the spotted owl (Strix occidentalis Xantus de Vesey). All three recognized subspecies of spotted owls (California
[S. o. occidentalis], Mexican [S. o. lucida Nelson], and northern [S. o. caurina Merriam]) typically nest in areas of high canopy cover within late seral forests (Forsman et al. 1984; Tempel et al. 2014, 2016; Ganey et al. 2016), although Mexican spotted owls also nest in rocky canyonlands (Willey and van Riper 2007, USDI FWS 2012). Due to stand density and abundance of dead material, most nesting stands have high fuel loads and therefore are vulnerable to high-severity wildfire. This is particularly true in drier forest types, but even mesic nesting stands can be vulnerable when embedded in landscapes dominated by drier forest types that are susceptible to crown fires following decades of fire suppression. Nesting habitat requires many decades to achieve structural conditions conducive to spotted owl nesting, and the loss of nesting habitat to high-severity fire has traditionally been viewed as a primary threat to the spotted owl (USDI FWS 2012). As a result, forest restoration treatments aimed at reducing fuel amounts and continuity have been proposed as a means to reduce risk of loss of spotted owl habitat to wildfire (James 2005, Lee and Irwin 2005, Gaines et al. 2010, USDI FWS 2012, Hagmann et al. 2017). Some authors argue against this approach, however, on the basis that high-severity fire was relatively common in many of these forest types, and large-scale restoration efforts therefore are unnecessary and, in fact, may degrade habitats for threatened and endangered species (Odion and Hanson 2006; Hanson et al. 2009a, b; Williams and Baker 2012; DellaSala et al. 2013; Odion et al. 2014; Baker 2015a, b; Bond 2016; Hutto et al. 2016). Further complicating this debate, the methods used and conclusions reached in 
some of these studies are not universally accepted among fire and forest ecologists (Fulé et al. 2014, Levine et al. 2017, O'Connor et al. 2017; but see Williams and Baker 2014).

Existing studies indicate that fuels reduction treatments may degrade habitat quality for spotted owls, however (Meiman et al. 2003; Seamans and Gutiérrez 2007; Stephens et al. 2014a; Tempel et al. 2014, 2015). Consequently, a conflicting viewpoint has emerged, suggesting that fuels-reduction treatments are unnecessary and misguided because they degrade owl habitat, do not reduce the extent of high-severity fire, and may result in greater loss of spotted owl habitat than wildfire alone would cause (Hanson et al. 2009a, b; DellaSala et al. 2013; Odion et al. 2014; Baker 2015b; Hanson and Odion 2016; but see Spies et al. 2009).

This conflict over whether high-severity wildfires or fuels treatments are potentially more damaging to spotted owls creates a dichotomy of perspectives regarding conserving spotted owls and their habitat. The resulting debate over tradeoffs among spotted owl habitat, wildfire, and restoration treatments has implications for management of vast tracts of forested land supporting numerous resources, as well as for how we integrate conservation of endangered species and their habitat with other resource management objectives (Hanson et al. 2009a, b; Spies et al. 2009; DellaSala et al. 2013; Odion et al. 2014; Baker 2015b; Hanson and Odion 2016).

Here, we argue that the existing literature is not sufficient to unambiguously quantify the response of spotted owls to high-severity wildfire, and that high-severity fire is pervasive enough within the range of the spotted owl to constitute a potential threat to owl habitat. We also provide evidence that forest restoration and fuels reduction treatments can mitigate fire behavior, but acknowledge that these treatments also can degrade spotted owl habitat. Based on these findings, we argue for cautious implementation of restoration treatments in or near spotted owl habitat, with the goal of identifying treatment types that successfully reduce fire risk while maintaining suitable habitat conditions for spotted owls.

These are complicated issues. Our intent is not to exhaustively review the existing literature on owl response to wildfire (recently reviewed in Bond 2016) or historic fire regimes within the range of the spotted owl, an area of ongoing debate (see above). Rather, we hope to clarify the limits to possible inference and caution against over-extrapolating results from existing studies in this debate. Below, we discuss some key points contributing to uncertainty over the response of spotted owls to high-severity wildfire, and recommend studies that would further our understanding on that response, as well as the response of spotted owls to fuel treatments. We focus our discussion on high-severity wildfire because it generally is perceived as a more pressing concern for spotted owls and their habitat than low-severity or moderate-severity wildfire.

\section{OWL RESPONSE DIFFERS AMONG STUDIES}

Although the recent literature contains numerous studies of the effects of fire on spotted owls, results of these studies do not indicate a consistent response by spotted owls. In cases in which multiple studies examined the same parameter, the results of those studies often showed a mix of responses (Table 1). For example, many studies showed no effects of wildfire on territory occupancy rates, whereas others showed negative effects, and studies that evaluated reproductive rates or use of foraging habitat showed responses ranging from positive to negative (Table 1). Only a single study to date presented long-term data on demographic performance of owls in burned areas, and that study also indicated variability among areas and fires (Rockweit et al. 2017). Thus, available data suggest considerable variation in responses of owls to wildfire. 
Table 1. Summary of studies evaluating the response of California (CSO), Mexican (MSO) and northern (NSO) spotted owls to high-severity wildfire. Also shown are parameters evaluated; whether or not salvage logging occurred in burned areas (No, Yes, or Unknown [UN]); number of owls, sites, or territories ( $\mathrm{T}=$ territories, $\mathrm{B}=$ number of burned territories) included; number of years post fire covered by the evaluation; and a simplified response $(+=$ generally positive, $0=$ neutral, $-=$ generally negative). The parameter occupancy was broadly defined here, and often included separate estimates of colonization and extinction rates. Number of territories and fires included, and number of years post fire covered by evaluation were estimated as best we could using information in the papers; that information was sometimes incomplete or unclear.

\begin{tabular}{|c|c|c|c|c|c|c|c|}
\hline Study & $\begin{array}{c}\text { Sub- } \\
\text { species }\end{array}$ & $\begin{array}{l}\text { Parameter } \\
\text { evaluated }\end{array}$ & $\begin{array}{l}\text { Salvage } \\
\text { logging }\end{array}$ & $\begin{array}{l}\text { Owls or } \\
\text { territories (n) }\end{array}$ & $\begin{array}{l}\text { Fires } \\
(n)\end{array}$ & $\begin{array}{l}\text { Years post } \\
\text { fire }(n)\end{array}$ & Response \\
\hline $\begin{array}{l}\text { Gutiérrez and Prichard } \\
1990\end{array}$ & $\mathrm{CSO}$ & Density & UN & UN & 1 & 1 & - \\
\hline \multirow{2}{*}{ Gaines et al. 1997} & $\mathrm{NSO}$ & Occupancy & UN & $6 \mathrm{~T}$ & 1 complex & 1 & - \\
\hline & & Reproduction & & & & & 0 \\
\hline \multirow{2}{*}{ Bond et al. 2002} & All & Survival & No & 21 owls & Multiple & 1 & 0 \\
\hline & & Reproduction & & $7 \mathrm{~T}$ & & 1 & + \\
\hline \multirow{2}{*}{ Jenness et al. 2004} & MSO & Occupancy & UN & $64 \mathrm{~T} ; 33 \mathrm{~B}$ & Multiple & 1 to 4 & - \\
\hline & & Reproduction & & & & & - \\
\hline \multirow{2}{*}{ Bond et al. 2009} & $\mathrm{CSO}$ & Foraging use & UN & 7 owls & 1 & 4 & + \\
\hline & & Roosting use & & & & & - \\
\hline \multirow{2}{*}{ Bond et al. 2010} & $\mathrm{CSO}$ & Winter moves & UN & 5 owls & 1 & 4 & 0 \\
\hline & & Roosting use & & & & & - \\
\hline Clark et al. 2011 & NSO & Survival & Yes & 23 owls & 2 & 3 to 4 & 0 \\
\hline Roberts et al. 2011 & $\mathrm{CSO}$ & Occupancy & No & 32 sites; 16 B & Multiple & 0 to 16 & 0 \\
\hline Lee et al. 2012 & $\mathrm{CSO}$ & Occupancy & & $186 \mathrm{~T} ; 41 \mathrm{~B}$ & Multiple & 1 to 6 & 0 \\
\hline Bond et al. 2013 & $\mathrm{CSO}$ & Home-range & UN & 7 owls & 1 & 4 & 0 \\
\hline Clark et al. 2013 & $\mathrm{NSO}$ & Occupancy & Yes & $143 \mathrm{~T} ; 40 \mathrm{~B}$ & Multiple & 1 to 5 & - \\
\hline \multirow{2}{*}{ Lee et al. 2013} & $\mathrm{CSO}$ & Occupancy & Yes & $168 \mathrm{~T}, 71 \mathrm{~B}$ & Multiple & 1 to 9 & 0 \\
\hline & & Reproduction & & & & & - \\
\hline Ganey et al. 2014b & MSO & Prey abundance & No & 4 owls & 2 & 4 to 6 & + \\
\hline Tempel et al. 2014 & $\mathrm{CSO}$ & Occupancy & Yes & $74 \mathrm{~T}$ & Unknown & Unknown & - \\
\hline Lee and Bond 2015a & $\mathrm{CSO}$ & Occupancy & Yes & $168 \mathrm{~T}$ & Multiple & 1 to 9 & - \\
\hline Lee and Bond $2015 b$ & $\mathrm{CSO}$ & Occupancy & No & $45 \mathrm{~T}$ & 1 & 1 & 0 \\
\hline \multirow{2}{*}{ Jones et al. 2016} & $\mathrm{CSO}$ & Occupancy & Yes & $45 \mathrm{~T} ; 30 \mathrm{~B}$ & 1 & 1 & - \\
\hline & & Foraging use & & 9 owls & & & - \\
\hline Bond et al. 2016 & $\mathrm{CSO}$ & Foraging use & $\mathrm{UN}$ & 8 owls & 1 & 4 & 0 \\
\hline Comfort et al. 2016 & $\mathrm{NSO}$ & Use of edge & Yes & 23 owls & 1 & 0 to 4 & - \\
\hline \multirow{2}{*}{ Rockweit et al. 2017} & NSO & Survival & No & $96 \mathrm{~T} ; 24 \mathrm{~B}$ & 10 & 0 to 25 & - \\
\hline & & Recruitment & & & & & - \\
\hline
\end{tabular}


Some of the variation among studies may reflect differences among geographic regions and forest types covered. All three subspecies of spotted owls inhabit forest types ranging from wet to fairly dry. For example, forests inhabited by northern spotted owls range from very mesic in places such as the Olympic Peninsula, Washington, to drier forest types on the eastern slope of the Cascade Mountains (Anthony et al. 2006). Similarly, California spotted owls inhabit relatively mesic conifer-dominated forests at higher elevations in the Sierra Nevada, but also inhabit oak (Quercus spp.) woodlands in the foothills and conifer-hardwood mixtures in the Peninsular Mountains of southern California (Verner et al. 1992). And Mexican spotted owls inhabit both rocky canyonlands and a range of forest types from wet mixed-conifer forests to drier pine-oak forest types (USDI FWS 2012). There is little reason to expect fire behavior to be similar across the range of occupied forest types, and therefore may be little reason to expect owl response to be similar among subspecies, geographic areas, and forest types. In this context, note that most of the available studies are on California spotted owls (Table 1). Far less information is available from the range of the northern and, especially, the Mexican spotted owl, and the responses of these subspecies may not be well described by studies of California spotted owls.

Some of the variation among studies also may stem from local variability among the fires themselves. Of particular interest here are recent studies by Lee and Bond (2015a) and Jones et al. (2016) in the same general area within the Sierra Nevada. Both studies evaluated occupancy rates of California spotted owls one year after large "megafires" (defined as fires that burned $\geq 10000$ ha; Stephens et al. 2014b) that burned in 2013 (Rim Fire; Lee and Bond 2015a) or 2014 (King Fire; Jones et al. 2016) and that included areas that burned with high severity. In the Rim Fire, Lee and Bond (2015a) concluded that owls were not negatively impacted by high-severity wildfire because occupancy rates for spotted owls were higher than previously published rates reported in either burned or long-unburned areas, and the amount of high-severity fire in designated owl Protected Activity Centers (Verner et al. 1992)did not affect pair occupancy. In contrast, Jones et al. (2016) concluded that high-severity wildfire negatively impacted owls and that megafires posed a threat to spotted owls because occupancy probability for spotted owls declined by $22 \%$ the year after the King Fire and declined by almost nine-fold in sites that burned at $>50 \%$ high severity.

Thus, studies of California spotted owls in two megafires in the same general area and time frame generated opposite conclusions regarding owl response to high-severity wildfire. Jones et al. (2016) hypothesized that the difference in results and conclusions reflected differences in the spatial pattern of areas that burned at high severity within each fire. High-severity patches were larger and more contiguous in the King Fire than in the Rim Fire (Figure 1) and overlapped numerous owl territories (Jones et al. 2016: figure 2). This explanation suggests that owl response is driven by the structure of the landscape mosaic that remains following wildfire. Where fires create a landscape with adequate amounts of remnant older forests, owls likely will be able to occupy that landscape (Bond 2016). In contrast, fires that create large patches that burn with high severity and leave inadequate amounts of remnant older forests are likely to render those areas unsuited for occupancy by spotted owls (Jones et al. 2016).

\section{MOST STUDIES DO NOT ADDRESS LONG-TERM RESPONSE TO HIGH-SEVERITY WILDFIRE}

Most studies of spotted owls in burned areas occurred less than four years post fire and therefore evaluated only short-term responses 


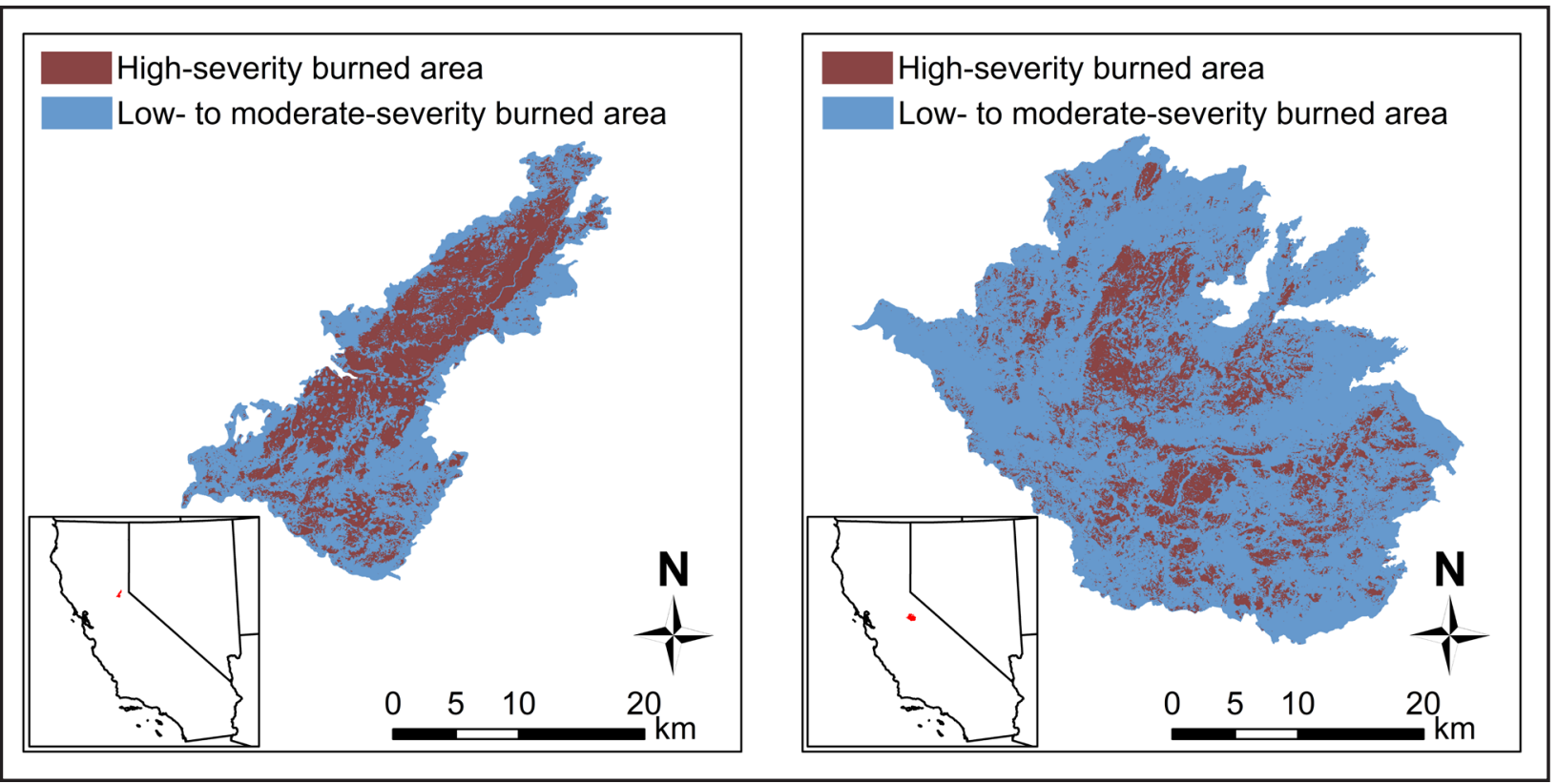

Figure 1. Maps showing fire severity within two recent megafires in the Sierra Nevada, within the range of the California spotted owl. The King Fire (left) burned 40106 ha in 2014, with 17419 ha burned at high severity (43.4\%). The Rim Fire (right) burned 104080 ha in 2013, with 20698 ha burned at high severity (19.9\%). Fire severity data obtained from USGS MTBS Project (2016). Scale is equal for both maps. The box in the lower left corner indicates the location of the fire within California.

(Table 1). Although some studies of California spotted owls included longer maximum post-fire periods, most of those studies included multiple fires that burned in different years (Roberts et al. 2011; Lee et al. 2012, 2013; Lee and Bond 2015b), with occupancy surveys conducted over the same years for all fires. Thus, for any given survey year, time since fire varied among fires. Results in these studies were pooled across fires, time since fire was not explicitly evaluated, and the relative proportion of data analyzed by post-fire period was not specified. Consequently, most data available on occupancy and use of burned areas by spotted owls is limited to the first few years post fire, and data showing that severely burned areas continue to be occupied by spotted owls over longer time frames range from sparse to nonexistent across subspecies (Table 1). Because spotted owls have relatively long lifespans and exhibit high site fidelity (Bond et al. 2002, Blakesley et al. 2006, Ganey et al. $2014 a$ ), continued short-term occupancy of burned areas could be partly due to site fidelity of pre-fire residents.

\section{STUDIES OF OCCUPANCY RATES MAY NOT BE SUFFICIENT TO EVALUATE OWL RESPONSE}

In addition to covering only short time frames, many studies of owl response to wildfire evaluated only occupancy rate or sometimes occupancy and reproduction (Table 1). Although these studies are valuable, those parameters alone are not sufficient to evaluate owl response. Only one study has reported on long-term demographic rates of marked owls following fire (Rockweit et al. 2017). Results again varied among fires evaluated. However, burned territories in some fires showed higher turnover in resident owls than unburned territories, but remained occupied over time despite that high turnover. The authors hypothesized that these burned territories functioned as population sinks with continued occupancy 
supported by immigration from nearby unburned source territories. This suggests that longer-term empirical data, using parameters that measure demographic rates of marked owls beyond territory occupancy and reproduction, are required to understand the effects of high-severity fire on spotted owls over a time frame relevant to population persistence.

\section{THE DURATION OF POST-FIRE POSITIVE EFFECTS ON FORAGING HABITAT IS UNKNOWN}

Spotted owls are known to forage in burned areas, including severely burned areas. The principal benefit to spotted owls from high-severity fire is hypothesized to be improved foraging habitat due to increases in small mammal abundance following fire (Bond et al. 2009, Bond 2016). There is evidence that some small mammals are more abundant following fire (Converse et al. 2006, Fontaine and Kennedy 2012, Ganey et al. $2014 a$ ), but results are not entirely consistent across taxa (Fontaine and Kennedy 2012, Roberts et al. 2015) and most studies of post-fire small mammal communities do not track abundance over long post-fire periods. A review by Fontaine and Kennedy (2012) found no studies of small mammals that tracked response for periods $>4 \mathrm{yr}$ post fire. Thus, for species of small mammals that show post-fire increases in abundance, the persistence of that increase is unknown.

The length of time during which spotted owls can forage effectively in severely burned areas also is unknown. Spotted owls hunt from elevated perches, and salvage logging in severely burned areas can quickly render large areas deficient of the elevated perches required for effective foraging (Bond 2016). Burned trees also fall quickly in some areas, however, so even unlogged areas may soon become deficient in elevated perches. For example, many unlogged areas in the Rodeo-Chediski megafire, Arizona, were largely devoid of standing snags by 14 years post fire (Figure 2). Elsewhere in Arizona ponderosa pine (Pinus ponderosa Laws) forests, $41 \%$ of snags fell within seven years following a wildfire (Chambers and Mast 2005), and coarse woody debris peaked between $6 \mathrm{yr}$ and $12 \mathrm{yr}$ post fire in two studies across chronosequences following wildfire (Passovoy and Fulé 2006, Roccaforte et al. 2012). This suggests that, at least in some areas or forest types, foraging habitat created by high-severity fire may be useful only for a short time. Ultimately, as snags fall, areas that are burned but not logged will provide the same low-quality foraging habitat reported by Bond (2016) for areas that are logged after fire. Note that salvage logging in spotted owl foraging habitat will hasten this process, however, and therefore still has negative consequences for spotted owl foraging habitat (Bond 2016).

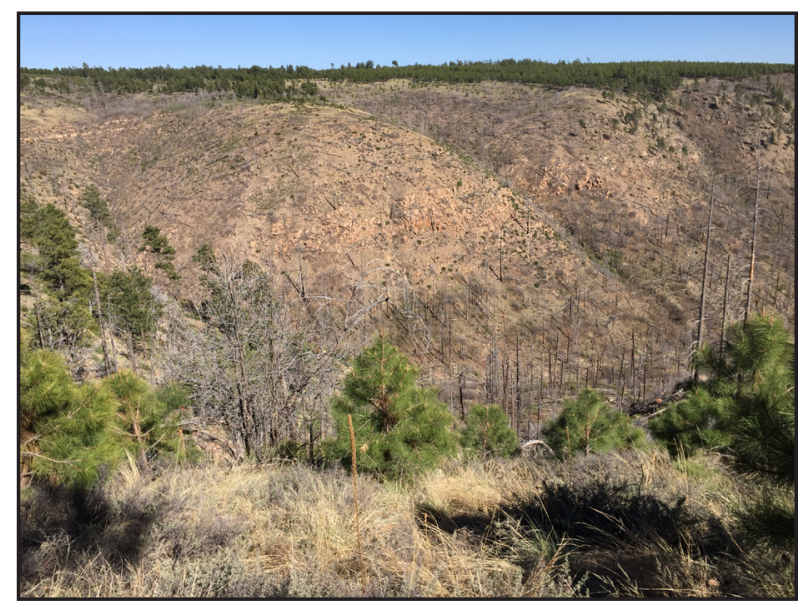

Figure 2. A severely burned area 14 years after the Rodeo-Chediski megafire, Arizona. Note that many snags remain standing within drainages, but in more exposed areas most snags have already fallen. As the remaining snags fall, large openings devoid of the elevated perches required by foraging owls will be created. 


\section{POTENTIAL IMPROVEMENTS IN FORAGING HABITAT DO NOT COMPENSATE FOR LOSS OF NESTING HABITAT}

Spotted owls selectively nest in forests featuring large trees and high canopy cover throughout their range (Forsman et al. 1984; Grubb et al. 1997; Hershey et al. 1998; May et al. 2004; Blakesley et al. 2005; Ganey et al. 2013, 2016; Tempel et al. 2014, 2016). Where such forests are available for nesting, owls will forage in a wide variety of forest and even non-forest cover types or edges (Call et al. 1992; Ward et al. 1998; Ganey et al. 1999, 2003; Comfort et al. 2016). Consequently, nesting habitat for spotted owls generally is considered more limited in amount and distribution than foraging habitat (USDI FWS 2012). As noted above, increase or improvement in owl foraging habitat from high-severity fire may be ephemeral, whereas the loss of nesting habitat is long-term, because regrowth of stands of large old trees with high canopy cover can take $>100$ yr. Thus, short-term gains in foraging habitat due to high-severity wildfire are unlikely to offset the loss of nesting habitat in the longer term.

\section{HIGH-SEVERITY WILDFIRE IS SUFFICIENTLY WIDESPREAD TO CONSTITUTE A POTENTIAL THREAT}

Proponents of the opinion that fire is not a threat to spotted owls may underestimate the potential extent and impact of high-severity wildfire. Bond (2016) argued that the number of owl territories subject to detrimental amounts of high-severity fire were likely to be small in any wildfire. This conclusion, however, may not be supported for megafires, which are large by definition and often include extensive areas that burn with high severity. The extent and severity of megafires has increased in recent decades (Miller et al. 2009, USDI FWS 2012) and they are predicted to likely increase as climate warms (McKenzie et al. 2004, Westerling et al. 2006, Littell et al. 2009), and impacts to owls and their habitat may be considerable (Stephens et al. 2016).

To assess the extent of megafires within the range of the spotted owl, we searched data from Monitoring Trends in Burn Severity (USGS MTBS Project 2016), a multi-year project designed to map fire perimeters and burn severity across all lands since 1984 (Eidenshink et al. 2007). We restricted our search to wildfires $>10000$ ha (after Stephens et al. 2014b) occurring on US Forest Service lands between 2000 and 2014 in the states of Arizona, California, New Mexico, Oregon, and Washington. The time period thus includes only recent fires, and roughly coincides with the period included in most studies of spotted owls and fire. By restricting the search to US Forest Service lands, we focused on areas most likely to harbor spotted owls. We did not include fires in Utah and Colorado, within the range of the Mexican spotted owl, because many owls in these areas occur in rocky canyonland habitat that may be less directly affected by fire (Willey and van Riper 2007 , USDI FWS 2012). We also used fire vicinity maps from USGS MTBS Project (2016) to eliminate fires outside of the range of the spotted owl within the states searched (i.e., east of the Cascade Mountains or Sierra Nevada), or in lowland valley areas unlikely to contain spotted owl territories.

Although our search was conservative and underestimated fire extent within the range of the spotted owl, we identified 105 megafires matching our search criteria (Supplemental Table 1, available from the senior author, lists the megafires used to develop the summary data in Tables 2 and 3, along with associated attribute data and data documentation. ). Fires $>100000$ ha occurred in the last 15 years within the ranges of all three owl subspecies, and individual fires burned $>50000$ ha at high severity within the range of all three subspecies (Table 2). These fires appear to have the po- 
Table 2. Mean and maximum area (ha) of "megafires" within the ranges of three subspecies of spotted owls between 1 January 2000 and 31 December 2014, and mean and maximum area burned at high severitya.

\begin{tabular}{|c|c|c|c|c|c|}
\hline \multirow[b]{2}{*}{ Subspecies } & \multirow[b]{2}{*}{$n$} & \multicolumn{2}{|c|}{ Fire area (ha) } & \multicolumn{2}{|c|}{$\begin{array}{l}\text { High severity } \\
\text { area (ha) }\end{array}$} \\
\hline & & Mean & Max & Mean & Max \\
\hline California & 37 & 33230 & 108599 & 9322 & 71605 \\
\hline Mexican & 33 & 44823 & 228103 & 5730 & 68408 \\
\hline Northern & 35 & 25537 & 200442 & 5408 & 58478 \\
\hline
\end{tabular}

tential to impact considerable numbers of owl territories, even within a single fire. This could place significant stress on local owl populations, particularly where owls occur in small insular populations within the range of California and Mexican spotted owls.

The cumulative effect of fire on spotted owls and their habitat is more detrimental than the effects of any single fire, however. The megafires identified in our search collectively burned 3567518 ha, including 723319 ha that burned with high severity (Table 3 ). We do not know how much of that area met conditions for spotted owl habitat; our point here is simply that these fires cumulatively burned an immense area and thus have the potential to

Table 3. Cumulative area burned and area burned at high severity (ha) in "megafires" within the ranges of three subspecies of spotted owls, between 1 January 2000 and 31 December 2014 ${ }^{a}$.

\begin{tabular}{lccc}
\hline Subspecies & $\begin{array}{c}\text { Megafire } \\
(\boldsymbol{n})\end{array}$ & $\begin{array}{c}\text { Area } \\
\text { burned (ha) }\end{array}$ & $\begin{array}{c}\text { High severity } \\
\text { area (ha) }\end{array}$ \\
\hline California & 37 & 1209475 & 340696 \\
Mexican & 33 & 1479175 & 189101 \\
Northern & 35 & 878868 & 193522 \\
\hline
\end{tabular}

${ }^{a}$ Data from Monitoring Trends in Burn Severity (USGS MTBS Project 2016). Only wildfires $>10000$ ha (Stephens et al. 2014b) on US Forest Service lands were included. impact considerable numbers of owl territories in a relatively short time period. These fires also created relatively large patches that burned with high severity (e.g., Figure 1).

The above analysis estimated overall area burned and was not restricted to the types of forest used for nesting by spotted owls. In a more focused analysis, Stephens et al. (2016) estimated area burned in potential California spotted owl nesting habitat in the Sierra Nevada and concluded that high-severity wildfire posed a significant threat to persistence of California spotted owl nesting habitat. Their analysis indicated that, between 2000 and 2014, 85046 ha of potential spotted owl nesting habitat was burned by wildfires, which resulted in $\geq 50 \%$ basal area mortality and reduced canopy cover to $<25 \%$. Area burned increased over the period from 1970 to 2014 (Stephens et al. 2016: figure 4), and a regression model based on that trend predicted that the cumulative amount of potential nesting habitat burned at $\geq 50 \%$ tree basal area mortality would exceed the amount of existing nesting habitat within 75 years (Stephens et al. 2016: figure 5). Similarly, USDI FWS (2012) concluded that megafires were the biggest threat facing Mexican spotted owls, based on the potential for rapid cumulative loss of nesting habitat to high-severity wildfire.

\section{FOREST RESTORATION TREATMENTS WARRANT FURTHER STUDY}

Forest restoration treatments have been proposed as a means to reduce fuels and fire risk, increase forest resiliency, and restore natural fire regimes (Covington and Moore 1994, Allen et al. 2002, Brown et al. 2004, Stanturf et al. 2014, Hagmann et al. 2017). There is empirical evidence that such treatments can modify fire severity, at least in drier forest types (Raymond and Peterson 2005, Prichard et al. 2010, Waltz et al. 2014, Roccaforte et al. 2015, Ziegler et al. 2017), and some (but not all) studies modeling fire behavior concluded 
that such treatments could modify both fire severity and extent, thus reducing the risk of loss of nesting habitat to high-severity wildfire (Lee and Irwin 2005, Ager et al. 2007, Cushman et al. 2011, Chiono et al. 2017; but see Odion et al. 2014, Baker 2015b, Hanson and Odion 2016). These treatments likely are unnecessary in areas where owls inhabit wetter forests characterized by long fire-free periods (Agee 1993)

Existing studies on the effects of fuels reduction treatments on spotted owls universally suggest negative effects from these treatments (Meiman et al. 2003, Seamans and Gutiérrez 2007, Stephens et al. 2014a, Tempel et al. 2014). These studies, however, are few in number, the mechanisms underlying owl response remain unclear, only short-term responses have been studied, and a limited range of treatment types have been evaluated. There may be important tradeoffs between shortterm impacts due to treatments and long-term benefits from those treatments due to reduction in the risk of high-severity fire (Lee and Irwin 2005, Ager et al. 2007, Tempel et al. 2015, Chiono et al. 2017). There also may be types of treatments that have not yet been evaluated that could reduce fire risk while maintaining habitat conditions suitable for spotted owls. Consequently, further studies aimed at understanding the effects of various types of restoration treatments on spotted owls are badly needed, as well as simulations of habitat trajectories with and without forest treatments (Lee and Irwin 2005, Ager et al. 2007, Odion et al. 2014, Tempel et al. 2015, Chiono et al. 2017).

\section{CONCLUSIONS}

Considerable uncertainty remains about the responses of spotted owls to wildfire, especially responses to high-severity fire over longer time frames and across subspecies. Relatively few studies have evaluated the effects of wildfires on spotted owls, especially for the
Mexican and northern subspecies, and results of existing studies are short-term and sometimes contradictory. To be clear, we do not assume that all wildfires are detrimental to spotted owls, and in fact surmise that low-severity and moderate-severity wildfires pose little threat to spotted owls. Available evidence suggests that high-severity wildfire can be detrimental, however, depending on spatial pattern and extent. The considerable recent extent of high-severity wildfire within the ranges of these subspecies (Table 3; see also Stephens et al. 2016), coupled with the trend toward increasing extent and severity of megafires (Miller et al. 2009, Stephens et al. 2016), suggests that the cumulative effects of these fires could be significant throughout the range of all three subspecies of the spotted owl.

Targeted research studies are needed to evaluate response of spotted owls to high-severity wildfire under different conditions of landscape pattern and in different forest types. Those studies should occur across a variety of forest types within the ranges of all three subspecies, should incorporate fires differing in size and extent and spatial pattern of high-severity fire, and should occur in the absence of salvage logging to avoid confounding fire effects with logging effects. We recommend studies of marked owls to provide information on the demography of populations within burned areas, rather than relying on estimates of occupancy rates (Tyre et al. 2001).

Forest restoration treatments may aid in reducing fire risk and habitat loss in some situations, particularly in drier forest types (Waltz et al. 2014, Roccaforte et al. 2015, Chiono et al. 2017, Ziegler et al. 2017). We acknowledge that not all such treatments will be beneficial to owls and their habitat. Implementing restoration treatments in and around owl habitat, therefore, is not without risk (USDI FWS 2012), and we urge caution in that implementation. Treatments should be located strategically based on models of fire behavior and spread to optimize gains in reduction of fire 
risk relative to area treated (Ager et al. 2007, 2010; Finney et al. 2007). Locating treatments outside of owl nesting habitat could reduce landscape-scale fire risk in proximity to owl nesting habitat while minimizing short-term impacts to such habitat (USDI FWS 2012; Stephens et al. 2014a, 2016; Tempel et al. 2015; Jones et al. 2016). When fire models indicate that treatments are needed within occupied owl habitat to reduce fire risk, treatments differing in intensity and spatial extent should be tested, and their effects on spotted owls should be carefully monitored, with the goal of identifying treatment types that successfully reduce fire risk while retaining habitat conditions suitable for spotted owls. Evaluating owl response to a range of treatment types that vary in extent and intensity, simulating extent and spatial pattern of habitat remaining in landscapes with and without such treatments, and coupling these models with demographic simulation models (e.g., Landguth and Cushman 2010), will help us understand tradeoffs between wildfire and restoration treatments with respect to conserving spotted owls and their habitat.

We also suggest that managers consider wider use of managed fire (both wild and prescribed) in the context of forest restoration (Collins et al. 2011, Hunter et al. 2011, Parks et al. 2014, North et al. 2015, Stephens et al. 2016, Huffman et al. 2017). Again, this is not without risk. Introducing or allowing fire to burn in owl habitat that features high fuel loads presents special challenges for fire managers. Nonetheless, allowing fire to burn in these areas when weather conditions are favorable (i.e., cool and wet with calm winds) could reduce the risk of high-severity fire while maintaining some of the habitat elements essential to spotted owls, as opposed to waiting for such areas to burn under the extremely hot, dry, and windy conditions characteristic of most megafires. Relative to mechanical treatments, managed fire is likely to be far more economical and may result in landscapes of greater spatial complexity preferred by spotted owls (Collins et al. 2011, Larson and Churchill 2012, Comfort et al. 2016). As with both wildfires and mechanical treatments, the effects of managed fire on owls and their habitat should be carefully evaluated.

The debate over spotted owls, wildfire, and forest restoration has important implications for management strategies over large forested landscapes, as well as for how we integrate conservation of threatened and endangered species and their habitats with other resource management objectives. This debate also involves numerous complicated issues. We do not pretend to resolve this debate here, but we hope that this paper stimulates productive dialogue among wildlife biologists, forest ecologists, and fire ecologists, and spurs additional research on historical fire regimes and wildfire and treatment effects on spotted owls and their habitat. Until better information is available on such effects, we argue that it is premature to conclude that high-severity wildfire poses no threat to spotted owls, or to dismiss restoration treatments as a tool in reducing fire risk and habitat loss.

\section{ACKNOWLEDGEMENTS}

The authors thank P. Beier, W. Block, S. Hedwall, J. Iniguez, J. Jenness, and M. Lommler for stimulating discussions on the topic discussed here (and wildfire effects in general). Comments by J.D. Wiens and two anonymous reviewers considerably improved an earlier version of this paper. 


\section{LITERATURE CITED}

Agee J.K. 1993. Fire ecology of Pacific Northwest forests. Island Press, Washington, D.C., USA.

Ager, A.A, M.A. Finney, B.K. Kerns, and H. Maffei. 2007. Modeling wildfire risk to northern spotted owl (Strix occidentalis caurina) habitat in central Oregon. Forest Ecology and Management 246: 45-56. doi: 10.1016/j.foreco.2007.03.070

Ager, A.A., N.M. Vaillant, and M.A. Finney. 2010. A comparison of landscape fuel treatment strategies to mitigate wildland fire risk in the urban interface and preserve old forest structure. Forest Ecology and Management 259: 1556-1570. doi: 10.1016/j.foreco.2010.01.032

Allen, C.D., M. Savage, D.A. Falk, K.F. Suckling, T.W. Swetnam, T. Schulke, P.B. Stacey, P. Morgan, M. Hoffman, and J.T. Klingel. 2002. Ecological restoration of Southwestern ponderosa pine ecosystems: a broad perspective. Ecological Applications 12: 1418-1433. doi: 10.1890/1051-0761(2002)012[1418:EROSPP]2.0.CO;2

Allen, C.D., A K. Macalady, H. Chenchouni, D. Bachelet, N. McDowell, M. Vennetier, T. Kitzberger, A. Rigling, D.D. Breshears, E.H. Hogg, P. Gonzalez, R. Fensham, Z. Zhang, J. Castro, N. Demidova, J.-H. Lim, G. Allard, S.W. Running, A. Semerci, and N. Cobb. 2010. A global overview of drought and heat-induced tree mortality reveals emerging climate change risks for forests. Forest Ecology and Management 259: 660-684. doi: 10.1016/j.foreco. 2009.09.001

Anthony, R.G., E.D. Forsman, A.B. Franklin, D.R. Anderson, K.P. Burnham, G.C. White, C.J. Schwarz, J.D. Nichols, J.E. Hines, G.S. Olson, S.H. Ackers, L.S. Andrews, B.L. Biswell, P.C. Carlson, L.V. Diller, K.M. Dugger, K.E. Fehring, T.L. Fleming, R.P. Gergardt, S.A. Gremel, R.J. Gutiérrez, P.J. Happe, D.R. Herter, J.M. Higley, R.B. Horn, L.L. Irwin, P.J. Loschl, J.A. Reid, and S.G. Sovern. 2006. Status and trends in demography of northern spotted owls, 1985-2003. Wildlife Monographs 163: 1-48. doi: 10.2193/0084-0173(2006)163[1: SATIDO]2.0.CO;2

Baker, W.L. 2015a. Are high-severity fires burning at much higher rates recently than historically in dry-forest landscapes of the western USA? PLoS ONE 10(9): e0136147. doi: 10.1371/ journal.pone.0136147

Baker, W.L. 2015b. Historical northern spotted owl habitat and old-growth dry forests maintained by mixed-severity wildfires. Landscape Ecology 30: 655-666. doi: 10.1007/ s10980-014-0144-6

Blakesley, J.A., B.R. Noon, and D.R. Anderson. 2005. Site occupancy, apparent survival, and reproduction of California spotted owls in relation to forest stand characteristics. Journal of Wildlife Management 69: 1554-1564. doi: 10.2193/0022-541X(2005)69[1554:SOASAR]2.0. $\mathrm{CO} ; 2$

Blakesley, J.A., D.R. Anderson, and B.R. Noon. 2006. Breeding dispersal in the California spotted owl. Condor 108: 71-81. doi: 10.1650/0010-5422(2006)108[0071:BDITCS]2.0.CO;2

Bond, M.L. 2016. The heat is on: spotted owls and wildfire. Reference module in earth systems and environmental sciences. Elsevier Press, Amsterdam, The Netherlands. <http://www.sciencedirect.com/science/article/pii/B9780124095489100144>. Accessed 15 August 2017.

Bond, M.L., R.J. Gutiérrez, A.B. Franklin, W.S. LaHaye, C.A. May, and M.E. Seamans. 2002. Short-term effects of wildfires on spotted owl survival, site fidelity, mate fidelity, and reproductive success. Wildlife Society Bulletin 30: 1022-1028. 
Bond, M.L., D.E. Lee, R.B. Siegel, and J.P. Ward Jr. 2009. Habitat use and selection by California spotted owls in a postfire landscape. Journal of Wildlife Management 73: 1116-1124. doi: $10.2193 / 2008-248$

Bond, M.L., D.E. Lee, and R.B. Siegel. 2010. Winter movements by California spotted owls in a burned landscape. Western Birds 41: 174-180.

Bond, M.L. D.E. Lee, R.B. Siegel, and M.W. Tingley. 2013. Diet and home-range size of California spotted owls in a burned forest. Western Birds 44: 114-126.

Bond, M.L., C. Bradley, and D.E. Lee. 2016. Foraging habitat selection by California spotted owls after fire. Journal of Wildlife Management 80: 1290-1300. doi: 10.1002/jwmg.21112

Brown, R.T., J.K. Agee, and J.F. Franklin. 2004. Forest restoration and fire: principles in the context of place. Conservation Biology 18: 903-912. doi: 10.1111/j.1523-1739.2004.521_1.x

Call, D.R., R.J. Gutiérrez, and J. Verner. 1992. Foraging habitat and home-range characteristics of California spotted owls in the Sierra Nevada. Condor 94: 880-888. doi: 10.2307/1369285

Chambers, C.L., and J.N. Mast. 2005. Ponderosa pine snag dynamics and cavity excavation following wildfire in northern Arizona. Forest Ecology and Management 216: 227-240. doi: 10.1016/j.foreco.2005.05.033

Chiono, L.A., D.L. Fry, B.M. Collins, A.H. Chatfield, and S.L. Stephens. 2017. Landscape-scale fuel treatment and wildfire impacts on carbon stocks and fire hazard in California spotted owl habitat. Ecosphere 8(1): e01648. doi: 10.1002/ecs2.1648

Clark, D.A., R.G. Anthony, and L.S. Andrews. 2011. Survival rates of northern spotted owls in post-fire landscapes of southwest Oregon. Journal of Raptor Research 45: 38-47. doi: 10.3356/JRR-10-42.1

Clark, D.A., R.G. Anthony, and L.S. Andrews. 2013. Relationship between wildfire, salvage logging, and occupancy of nesting territories by northern spotted owls. Journal of Wildlife Management 77: 672-688. doi: 10.1002/jwmg.523

Collins, B.M., R.G. Everett, and S.L. Stephens. 2011. Impacts of fire exclusion and recent managed fire on forest structure in old growth Sierra Nevada mixed-conifer forests. Ecosphere 2(4): article 51. doi: 10.1890/ES11-00026.1

Comfort, E.J., D.A. Clark, R.G. Anthony, J. Bailey, and M.G. Betts. 2016. Quantifying edges as gradients at multiple scales improves habitat selection models for northern spotted owl. Landscape Ecology 31: 1227-1240. doi: 10.1007/s10980-015-0330-1

Converse, S.J., W.M. Block, and G.C. White. 2006. Small mammal population and habitat responses to forest thinning and prescribed fire. Forest Ecology and Management 228: 263273. doi: 10.1016/j.foreco.2006.03.006

Covington, W.W., and M.M. Moore. 2004. Postsettlement changes in natural fire regimes and forest structure: ecological restoration of old-growth ponderosa pine forests. Journal of Sustainable Forestry 2: 153-181. doi: 10.1300/J091v02n01_07

Cushman, S.A., T.N. Wasserman, and K. McGarigal. 2011. Modeling landscape fire and wildlife habitat. Pages 223-245 in: D. McKenzie, C. Miller, and D.A. Falk, editors. The landscape ecology of fire. Springer Science and Business Media, New York, New York, USA. doi: 10.1007/978-94-007-0301-8_9

DellaSala, D.A., R.G. Anthony, M. L. Bond, E.S. Fernandez, C.A. Frissell, C.T. Hanson, and R. Spivak. 2013. Alternative views of a restoration framework for federal forests in the Pacific Northwest. Journal of Forestry 111: 420-429. doi: 10.5849/jof.13-040

Eidenshink, J.C., B. Schwind, K. Brewer, Z.-L. Zhu, B. Quayle, and S.M. Howard. 2007. A project for monitoring trends in burn severity. Fire Ecology 3: 3-21. doi: 10.4996/ fireecology.0301003 
Finney, M.A., R.C. Seli, C.W. McHugh, A.A. Ager, B. Bahro, and J.K Agee. 2007. Simulation of long-term landscape-level fuel treatment effects on large wildfires. International Journal of Wildland Fire 16: 712-727. doi: 10.1071/WF06064

Fontaine, J.B., and P.L. Kennedy. 2012. Meta-analysis of avian and small-mammal response to fire severity and fire surrogate treatments in US fire-prone forests. Ecological Applications 22: 1547-1561. doi: 10.1890/12-0009.1

Forsman, E.D., E.C. Meslow, and H.M. Wight. 1984. Distribution and biology of the spotted owl in Oregon. Wildlife Monographs 87: 1-64.

Fulé, P.Z., T.W. Swetnam, P.M. Brown, D.A. Falk, D.L. Peterson, C.D. Allen, G.H. Aplet, M.A. Battaglia, D. Binkley, and C. Farris. 2014. Unsupported inferences of high-severity fire in historical dry forests of the western United States: response to Williams and Baker. Global Ecology and Biogeography 23: 825-830. doi: 10.1111/geb.12136

Gaines, W.L., R.A. Strand, and S.D. Piper. 1997. Effects of the Hatchery Complex Fires on northern spotted owls in the eastern Washington Cascades. Pages 123-129 in: J.M. Greenlee, editor. Fire effects on rare and endangered species and habitats. International Association of Wildland Fire, Coeur d'Alene, Idaho, USA.

Gaines, W.L., R.J. Harrod, J. Dickinson, A.L. Lyons, and K. Halupka. 2010. Integration of northern spotted owl habitat and fuels treatments in the eastern Cascades, Washington, USA. Forest Ecology and Management 260: 2045-2052. doi: 10.1016/j.foreco.2010.09.011

Ganey, J.L., W.M. Block, J.S. Jenness, and R.A. Wilson. 1999. Mexican spotted owl home range and habitat use in pine-oak forest: implications for forest management. Forest Science 45: $127-135$.

Ganey, J.L., W.M. Block, and S.H. Ackers. 2003. Structural characteristics of forest stands within home ranges of Mexican spotted owls in Arizona and New Mexico. Western Journal of Applied Forestry 18: 189-198.

Ganey, J.L., D.L. Apprill, T.A. Rawlinson, S.C. Kyle, R.S. Jonnes, and J.P. Ward Jr. 2013. Nesting habitat of Mexican spotted owls in the Sacramento Mountains, New Mexico. Journal of Wildlife Management 77: 1426-1435. doi: 10.1002/jwmg.599

Ganey, J.L., D.L. Apprill, S.C. Kyle, T.A. Rawlinson, R.S. Jonnes, and J.P. Ward Jr. $2014 a$. Breeding dispersal of Mexican spotted owls in the Sacramento Mountains, New Mexico. Wilson Journal of Ornithology 126: 516-524. doi: 10.1676/14-004.1

Ganey, J.L., S.C. Kyle, T.A. Rawlinson, D.L. Apprill, and J.P. Ward Jr. 2014b. Relative abundance of small mammals in nest core areas and burned wintering areas of Mexican spotted owls in the Sacramento Mountains, New Mexico. Wilson Journal of Ornithology 126: 47-52. doi: $10.1676 / 13-117.1$

Ganey, J.L., J.M. Iníguez, S. Hedwall, W.M. Block, J.P. Ward Jr., R.S. Jonnes, T.A. Rawlinson, S.C. Kyle, and D.L. Apprill. 2016. Evaluating desired conditions for Mexican spotted owl nesting and roosting habitat. Forest Science 62: 457-462. doi: 10.5849/forsci.15-027

Grubb, T.G., J.L. Ganey, and S.R. Masek. 1997. Canopy closure around nest sites of Mexican spotted owls in northcentral Arizona. Journal of Wildlife Management 61: 336-342. doi: $10.2307 / 3802589$

Gutiérrez, R.J., and J. Pritchard. 1990. Distribution, density, and age structure of spotted owls on two southern California habitat islands. Condor 92: 491-495. doi: 10.2307/1368246

Hagmann, R.K., D.L. Johnson, and K.N. Johnson. 2017. Historical and current forest conditions in the range of the northern spotted owl in south central Oregon, USA. Forest Ecology and Management 389: 374-385. doi: 10.1016/j.foreco.2016.12.029 
Hanson, C.T., D.C. Odion, D.A. DellaSala, and W.L. Baker. 2009a. Overestimation of fire risk in the Northern Spotted Owl Recovery Plan. Conservation Biology 23: 1314-1319. doi: 10.1111/j.1523-1739.2009.01265.x

Hanson, C.T., D.C. Odion, D.A. DellaSala, and W.L. Baker. 2009b. More-comprehensive recovery actions for northern spotted owls in dry forests: reply to Spies et al. Conservation Biology 24: 334-337. doi: 10.1111/j.1523-1739.2009.01415.x

Hanson, C.T., and D.C. Odion. 2016. Historical forest conditions within the range of the Pacific fisher and spotted owl in the central and southern Sierra Nevada, California, USA. Natural Areas Journal 36: 8-19. doi: 10.3375/043.036.0106

Hershey, K.T., E.C. Meslow, and F.L. Ramsey. 1998. Characteristics of forests at spotted owl nest sites in the Pacific Northwest. Journal of Wildlife Management 62: 1398-1410. doi: $10.2307 / 3802006$

Huffman, D.W., A.J. Sanchez Meador, M.T. Stoddard, J.E. Crouse, and J.P. Roccaforte. 2017. Efficacy of resource objective wildfires for restoration of ponderosa pine (Pinus ponderosa) forests in northern Arizona. Forest Ecology and Management 389: 395-403. doi: 10.1016/j. foreco.2016.12.036

Hunter, M.E., J.M. Iniguez, and L.B. Lentile. 2011. Short- and long-term effects on fuels, forest structure, and wildfire potential from prescribed fire and resource benefit fire in Southwestern forests, USA. Fire Ecology 7(3): 108-121. doi: 10.4996/fireecology.0703108

Hutto, R.L., R.E. Keane, R.L. Sherriff, C.T. Rota, L.A. Eby, and V.A. Saab. 2016. Toward a more ecologically informed view of severe forest fires. Ecosphere 7(2): e01255. doi: $10.1002 /$ ecs 2.1255

James, M. 2005. Integrating forest restoration treatments with Mexican spotted owl habitat needs. Working papers in Southwestern ponderosa pine forest restoration 14. Ecological Restoration Institute, Flagstaff, Arizona, USA.

Jenness, J.S., P. Beier, and J.L. Ganey. 2004. Associations between forest fire and Mexican spotted owls. Forest Science 50: 765-772.

Jones, G.M., R.J. Gutiérrez, D.J. Tempel, S.A. Whitmore, W.J. Berigan, and M.Z. Peery. 2016. Megafires: an emerging threat to old-forest species. Frontiers in Ecology and the Environment 14: 300-306. doi: 10.1002/fee.1298

Keane, R.E., P.F. Hessburg, P.B. Landres, and F.J. Swanson. 2009. The use of historical range of variability (HRV) in landscape management. Forest Ecology and Management 258: 10251037. doi: 10.1016/j.foreco.2009.05.035

Landguth, E.L., and S.A. Cushman. 2010. CDPOP: a spatially explicit cost distance population genetics program. Molecular Ecology Resources 10: 156-161. doi: 10.1111/j.1755-0998.2009.02719.x

Larson, A.J., and D. Churchill. 2012. Tree spatial patterns in fire-frequent forests of western North America, including mechanisms of pattern formation and implications for designing fuel reduction and restoration treatments. Forest Ecology and Management 267: 74-92. doi: 10.1016/j.foreco.2011.11.038

Lee, D.C., and L.L. Irwin. 2005. Assessing risks to spotted owls from forest thinning in fire-adapted forests of the western United States. Forest Ecology and Management 211: 191209. doi: 10.1016/j.foreco.2005.02.001

Lee, D.E., and M.L. Bond. 2015a. Occupancy of California spotted owl sites following a large fire in the Sierra Nevada, California. Condor 117: 228-236. doi: 10.1650/ CONDOR-14-155.1 
Lee, D.E., and M.L. Bond. 2015b. Previous year's reproductive state affects spotted owl site occupancy and reproduction responses to natural and anthropogenic disturbances. Condor 117: 307-319. doi: 10.1650/CONDOR-14-197.1

Lee, D.E., M.L. Bond, and R.S. Siegel. 2012. Dynamics of California spotted owl breeding-season site occupancy in burned forests. Condor 114: 792-802. doi: 10.1525/cond.2012.110147

Lee, D.E., M.L. Bond, M.I. Borchert, and R. Tanner. 2013. Influence of fire and salvage logging on site occupancy of spotted owls in the San Bernardino and San Jacinto mountains of southern California. Journal of Wildlife Management 77: 1327-1341. doi: 10.1002/jwmg.581

Levine, C.R., C.V. Cogbill, B.M. Collins, A.J. Larson, J.A. Lutz, M.P. North, C.M. Restaino, H.D. Safford, S.L. Stephens, and J.J. Battles. 2017. Evaluating a new method for reconstructing forest conditions from General Land Office survey records. Ecological Applications 27(5): 1498-1513. doi: 10.1002/eap.1543

Littell, J.S., D. McKenzie, D.L. Peterson, and A.L. Westerling. 2009. Climate and wildfire area burned in western US ecoprovinces, 1916-2003. Ecological Applications 19: 1003-1021. doi: 10.1890/07-1183.1

McKenzie, D., Z. Gedalof, D.L. Peterson, and P. Mote. 2004. Climatic change, wildfire, and conservation. Conservation Biology 18: 890-902. doi: 10.1111/j.1523-1739.2004.00492.x

May, C.A., M.L. Petersburg, and R.J. Gutiérrez. 2004. Mexican spotted owl nest- and roost-site habitat in northern Arizona. Journal of Wildlife Management 68: 1054-1064. doi: 10.2193/0022-541X(2004)068[1054:MSONAR]2.0.CO;2

Meiman, S., R. Anthony, E. Glenn, T. Bayless, A. Ellingson, M.C. Hansen, and C. Smith. 2003. Effects of commercial thinning on home-range and habitat-use patterns of a male northern spotted owl: a case study. Wildlife Society Bulletin 31: 1254-1262.

Miller, J.D., H.D. Safford, M. Crimmins, and A. E. Thode. 2009. Quantitative evidence for increasing forest fire severity in the Sierra Nevada and southern Cascade Mountains, California and Nevada, USA. Ecosystems 12: 16-32. doi: 10.1007/s10021-008-9201-9

Miller, J.D., and H.D. Safford. 2012. Trends in wildfire severity: 1984 to 2010 in the Sierra Nevada, Modoc Plateau, and southern Cascades, California, USA. Fire Ecology 8(3): 41-57. doi: 10.4996/fireecology.0803041

North, M., P.A. Stine, K.L. O'Hara, W.J. Zielinski, and S.L. Stephens. 2009. An ecosystem management strategy for Sierra mixed-conifer forests, with addendum. USDA Forest Service General Technical Report PSW-GTR-220, Pacific Southwest Research Station, Albany, California, USA.

North, M.P., S.L. Stephens, B.M. Collins, J.K. Agee, G. Aplet, J.F. Franklin, and P.Z. Fulé 2015. Reform forest fire management: agency incentives undermine policy effectiveness. Science 349: 1280-1281. doi: 10.1126/science.aab2356

O'Connor, C.D., D.A. Falk, A.M. Lynch, T.W. Swetnam, and C.P. Wilcox. 2017. Disturbance and productivity interactions mediate stability of forest composition and structure. Ecological Applications 27: 900-915. doi: 10.1002/eap.1492

Odion, D.C., and C.T. Hanson. 2006. Fire severity in conifer forests of the Sierra Nevada, California. Ecosystems 9: 1177-1189. doi: 10.1007/s10021-003-0134-z

Odion, D.C., C.T. Hanson, D.A. DellaSala, W.L. Baker, and M.L. Bond. 2014. Effects of fire and commercial thinning on future habitat of the northern spotted owl. Open Ecology Journal 7: 37-51. doi: 10.2174/1874213001407010037

Parks, S.A., C. Miller, C.R. Nelson, and Z.A. Holden. 2014. Previous fires moderate burn severity of subsequent wildland fires in two large western US wilderness areas. Ecosystems 17: 29-42. doi: 10.1007/s10021-013-9704-x 
Passovoy, M.D., and P.Z. Fulé. 2006. Snag and woody debris dynamics following severe wildfires in northern Arizona ponderosa pine forests. Forest Ecology and Management 223: 237246. doi: 10.1016/j.foreco.2005.11.016

Prichard, S.J., D.L. Peterson, and K. Jacobson. 2010. Fuel treatments reduce the severity of wildfire effects in dry mixed conifer forest, Washington, USA. Canadian Journal of Forest Research 40: 1615-1626. doi: 10.1139/X10-109

Raymond, C.L., and D.L. Peterson. 2005. Fuel treatments alter the effects of wildfire in a mixed evergreen forest, Oregon, USA. Canadian Journal of Forest Research 35: 2981-2995. doi: 10.1139/x05-206

Roberts, S.L., J.W. van Wagtendonk, A.K. Miles, and D.A. Kelt. 2011. Effects of fire on spotted owl site occupancy in a late successional forest. Biological Conservation 144: 610-619. doi: 10.1016/j.biocon.2010.11.002

Roberts, S.L., D.A. Kelt, J.W. van Wagtendonk, A.K. Miles, and J.D. Meyer. 2015. Effects of fire on small mammal communities in frequent-fire forests in California. Journal of Mammalogy 96: 107-119. doi: 10.1093/jmammal/gyu011

Roccaforte, J.P., P.Z. Fulé, and W.W. Covington. 2010. Monitoring landscape-scale ponderosa pine restoration treatment implementation and effectiveness. Restoration Ecology 18: 820833. doi: 10.1111/j.1526-100X.2008.00508.x

Roccaforte, J.P., P.Z. Fulé, W.W. Chancellor, and D.C. Laughlin. 2012. Woody debris and tree regeneration dynamics following severe wildfires in Arizona ponderosa pine forests. Canadian Journal of Forest Research 42: 593-604. doi: 10.1139/x2012-010

Roccaforte, J.P., D.W. Huffman, P.Z. Fulé, W.W. Covington, W.W. Chancellor, M.T. Stoddard, and J.E. Crouse. 2015. Forest structure and fuels dynamics following ponderosa pine restoration treatments, White Mountains, Arizona, USA. Forest Ecology and Management 337: 174-185. doi: 10.1016/j.foreco.2014.11.001

Rockweit, J.T., A.B. Franklin, and P.C. Carlson. 2017. Differential impacts of wildfire on the population dynamics of an old-forest species. Ecology 98(6): 1574-1582. doi: 10.1002/ ecy.1805

Seamans, M.E., and R.J. Gutiérrez. 2007. Habitat selection in a changing environment: the relationship between habitat alteration and spotted owl territory occupancy and breeding dispersal. Condor 109: 566-576. doi: 10.1650/8352.1

Sisk, T.D., M. Savage, D.A. Falk, C.D. Allen, E. Muldavin, and P. McCarthy. 2005. A landscape perspective for forest restoration. Journal of Forestry 103(6): 319-320.

Spies, T.A., J.D. Miller, J.B. Buchanan, J.F. Lehmkuhl, J.F. Franklin, S.P. Healey, P.F. Hessburg, H.D. Safford, W.B. Cohen, R.S.H. Kennedy, E.E. Knapp, J.K. Agee, and M. Moeur. 2009. Underestimating risks to the northern spotted owl in fire-prone forests: response to Hanson et al. Conservation Biology 24: 330-333. doi: 10.1111/j.1523-1739.2009.01414.x

Stanturf, J.A., B.J. Palik, and R.K. Dumroese. 2014. Contemporary forest restoration: a review emphasizing function. Forest Ecology and Management 331: 292-323. doi: 10.1016/j. foreco.2014.07.029

Stephens, S.L., S.W. Bigelow, R.D. Burnett, B.M. Collins, C.V. Gallagher, J. Keane, D.A. Kelt, M.P. North, L.J. Roberts, P.A. Stine, and D.H. Van Vuren. 2014a. California spotted owl, songbird, and small mammal responses to landscape fuel treatments. BioScience 64: 893906. doi: 10.1093/biosci/biu137 
Stephens, S.L., N. Burrows, A. Buyantuyev, R.W. Gray, R.E. Keane, R. Kubian, S. Liu, F. Seijo, L. Shu, K.G. Tolhurst, and J.W. van Wagtendonk. 2014b. Temperate and boreal forest mega-fires: characteristics and challenges. Frontiers in Ecology and the Environment 12: 11522. doi: 10.1890/120332

Stephens, S.L., J.D. Miller, B.M. Collins, M.P. North, J.J. Keane, and S.L. Roberts. 2016. Wildfire impacts on California spotted owl nesting habitat in the Sierra Nevada. Ecosphere 7(11): e01478. doi: 10.1002/ecs2.1478

Tempel, D.J., R.J. Gutiérrez, S.A. Whitmore, M.J. Reetz, R.E. Stoelting, W.J. Berigan, M.E. Seamans, and M.Z. Peery. 2014. Effects of forest management on California spotted owls: implications for reducing wildfire risk in fire-prone forests. Ecological Applications 24: 20892106. doi: 10.1890/13-2192.1

Tempel, D.J., R.J. Gutiérrez, J.J. Battles, D.L. Fry, Y. Su, Q. Guo, M.J. Reetz, S.A. Whitmore, G.M. Jones, B.M. Collins, S.L. Stephens, M. Kelly, W.J. Berigan, and M.Z. Peery. 2015. Evaluating short- and long-term impacts of fuels treatments and simulated wildfire on an old-forest species. Ecosphere 6: 261. doi: 10.1890/ES15-00234.1

Tempel, D.J., J.J. Keane, R.J. Gutiérrez, J.D. Wolfe, G.M. Jones, A. Koltunov, C.M. Ramirez, W.J. Berigan, C.V. Gallagher, T.E. Munton, P.A. Shaklee, S.A. Whitmore, and M.Z. Peery. 2016. Meta-analysis of California spotted owl (Strix occidentalis occidentalis) territory occupancy in the Sierra Nevada: habitat associations and their implications for forest management. Condor 118: 747-765. doi: 10.1650/CONDOR-16-66.1

Tyre, A.J., H.P. Possingham, and D.B. Lindenmayer. 2011. Inferring process from pattern: can territory occupancy provide information about life history parameters. Ecological Applications 11: 1722-1737. doi: 10.1890/1051-0761(2001)011[1722:IPFPCT]2.0.CO;2

USDI Fish and Wildlife Service. 2012. Mexican spotted owl recovery plan, first revision (Strix occidentalis lucida). USDI Fish and Wildlife Service, Albuquerque, New Mexico, USA.

USGS MTBS Project [US Geological Survey Monitoring Trends in Burn Severity]. 2016. Monitoring Trends in Burn Severity. <http://www.mtbs.gov>. Accessed 13 December 2016.

Verner, J., R.J. Gutiérrez, and G.I. Gould Jr. 1992. The California spotted owl: general biology and ecological relations. Pages 55-77 in: J. Verner, K.S. McKelvey, B.R. Noon, R.J. Gutiérrez, G.I. Gould Jr., and T.W. Beck. The California spotted owl: a technical assessment of its current status. USDA Forest Service General Technical Report PSW-GTR-133, Pacific Southwest Research Station, Albany, California, USA.

Waltz, A.E.M., M.T. Stoddard, E.L. Kalies, J.D. Springer, D.W. Huffman, and A. Sánchez Meador. 2014. Effectiveness of fuel reduction treatments: assessing metrics of forest resiliency and wildfire severity after the Wallow Fire, AZ. Forest Ecology and Management 334: 43-52.

Ward, J.P., Jr., R.J. Gutiérrez, and B.R. Noon. 1998. Habitat selection by northern spotted owls: the consequences of prey selection and distribution. Condor 100: 79-92. doi: $10.2307 / 1369899$

Westerling, A., H. Hidalgo, D. Cayan, and T. Swetnam. 2006. Warming and earlier spring increase western US forest wildfire activity. Science 313: 940-943. doi: 10.1126/ science. 1128834

Willey, D.W., and C. van Riper III. 2007. Home range characteristics of Mexican spotted owls in the canyonlands of Utah. Journal of Raptor Research 41: 10-15. doi: 10.3356/ 0892-1016(2007)41[10:HRCOMS]2.0.CO;2 
Williams, M.A., and W.L. Baker. 2012. Spatially extensive reconstructions show variable-severity fire and heterogeneous structure in historical western United States dry forests. Global Ecology and Biogeography 21: 1042-1052. doi: 10.1111/j.1466-8238.2011.00750.x

Williams, M.A., and W.L. Baker. 2014. High-severity fire corroborated in historical dry forests of the western United States: response to Fulé etal. Global Ecology and Biogeography 23: 831-835. doi: 10.1111/geb.12152

Ziegler, J.P., C. Hoffman, M. Battaglia, and W. Mell. 2017. Spatially explicit measurements of forest structure and fire behavior following restoration treatments in dry forests. Forest Ecology and Management 386: 1-12. doi: 10.1016/j.foreco.2016.12.002 